\title{
MulawarmanLawReview
}

\section{Towards a Reformed Carriage of Goods by Sea Law: Indonesia and Global Practice}

\author{
Atur Tetty Lubis \\ International Business Law Program, Prasetiya Mulya University, Jakarta, Indonesia. \\ E-mail: tettylubis@yahoo.com
}

\begin{abstract}
The UNCITRAL (United Nations Commission on International Trade Law) has adopted four international conventions to standardize laws governing the carriage of goods by sea. Hybrid versions of the four conventions have been largely applied by most maritime countries in the world, which leave a few countries to uphold their own versions, including Indonesia. Ten major trading partner countries with Indonesia have long established the implementation of provisions under the UNCITRAL conventions, while Indonesia still stays with 1898 codes, inherited from Dutch colonization. This paper examines the key provisions and shortcomings of UNCITRAL conventions and their global adoption. The discussion continues to individually evaluate and compare the legal practices of governing carriage goods by sea in Indonesia and its ten major country partners. The comparison analysis results in similar implementation of a hybrid version of the four UNCITRAL conventions adopted by the ten trading partners; which strongly encourages Indonesia to replace the 1898 commercial codes with current international practices that convey the best interests of Indonesia.
\end{abstract}

Keywords: Carriage of Goods by Sea; Hague Rules; Hague Visby Rules; Hamburg Rules; Rotterdam Rules; UNCITRAL.

Citation: Lubis, Tetty. 2020. "Towards a Reformed Carriage of Goods by Sea Law: Indonesia and Global Practice". Mulawarman Law Review 5 (1), 61-79. https://doi.org/10.30872/mulrev.v5i1.330.

\section{INTRODUCTION}

A remarkable development has occurred in the maritime sphere of South East Asia. Ten countries in the region with emerging economic development have established a commercial and economic integration agreement under a regional economic association called ASEAN. ${ }^{1}$ ASEAN's goal to become a free trade zone within the ten countries is set to its achievement through the establishment of ASEAN Economic Community (AEC) in 2015, where ASEAN leaders adopted the AEC Blueprint 2025 that provides broad directions through strategic measures for the AEC from 2016 to 2025 . $^{2}$

The 2015 AEC establishment was a major milestone in the regional economic integration agenda in ASEAN, offering opportunities in the form of a huge market of US\$2.6 trillion and over 622 million people. That makes AEC collectively be the third

\footnotetext{
${ }^{1}$ ASEAN (n.d.). ASEAN Member States. Available from: https://asean.org/asean/asean-member-states/ [Accessed May 20, 2020]

2 ASEAN (n.d.). ASEAN Economic Community. Available from: https://asean.org/asean-economiccommunity/ [Accessed June 21, 2020 https://asean.org/asean-economic-community/
} 
largest economy in Asia and the seventh largest in the world in year of 2015, and spurred to the fifth global position in 2018 with a combined GDP of $\$ 3$ trillion. ${ }^{3}$

Indonesia as the biggest maritime state has not only advantages but also obstacles in managing sea. Called potential because of its large resources but it also brings into a fact of the lack in exploitation of the sea. ${ }^{4}$ Indonesia, a founding father of ASEAN, has been named by World Bank as the largest economy in Southeast Asia and the world's 10th largest economy in terms of purchasing power parity, and a member of the G-20. ${ }^{5}$ Indonesia also has been widely known as the world's largest archipelago with a sea area of around 7.9 million square kilometers including the EEZ (Exclusive Economic Zone), some four times larger than the land area. Indonesia is greatly reliant on maritime transport for both international and domestic trade especially because of its archipelagic nature, based on which the Indonesian government has proudly proclaimed the country as a maritime nation and ascertained the maritime sector as a key area for economic development. ${ }^{6}$

The ambition to become a maritime nation is acceptably grounded yet challenging; the government should pay strong attention to the delicate balance of trade and law, which should also be anticipated in combination with the changing condition of the economy. From the legal perspective, the domestic trade laws with respect to the carriage of goods by sea have to be efficiently regulated to conform to the global standards. If there is a proposal for a new direction, it should be steered towards the best interests of Indonesia and current international practice. ${ }^{7}$

At present, even though Indonesia has adopted Law no.17 of 2008 on shipping, but the maritime industry in the country is still profoundly bound by the 1848 commercial codes inherited from the Dutch colonialism as the 2008 shipping law leaves numerous substantial issues on carrying goods by sea unregulated. ${ }^{8}$ Besides, since the adoption in 2008, the shipping law has yet come into force, leaving business community to rely only their legal reference in carriage of goods by sea on the 1848 commercial codes, which are certainly incompatible with the rapid development of technology and communication in the maritime industry. The carrier's minimum liability was set based on the condition of trading over 160 years ago, when only few countries traded globally and containerization had yet existed. Therefore Indonesian laws are widely

\footnotetext{
3 ASEAN (n.d.). ASEAN Economic Community. Available from: https://asean.org/asean-economiccommunity/ [Accessed June 21, 2020 https://asean.org/asean-economic-community/

${ }^{4}$ Sirait, Y. H., \& Ai Permanasari. (2020). Marine Litter Management Policy: State Responsibilities And The Role Of Local Wisdom. Mulawarman Law Review, 5(1), 18-28. https://doi.org/10.30872/mulrev.v5i1.307

5 World Bank (n.d.) The World Bank in Indonesia. Available from: https://www.worldbank.org/en/country/indonesia/overview [Accessed May 20, 2020]

${ }^{6}$ Cribb, R., \& Ford, M. (2009). Indonesia as an Archipelago: Managing Islands, Managing the Seas. In R. Cribb \& M. Ford (Eds.), Indonesia beyond the Water's Edge: Managing an Archipelagic State (pp. 1-27). ISEAS-Yusof Ishak Institute.

7 Parameswaran, P. (2015). Indonesia's Maritime Ambition: Can Jokowi Realise It? RSIS Commentary, p. 44

${ }^{8}$ Azka R. (2019, August 14) Revisi UU Pelayaran: INSA: Waspadai Intervensi Asing, Bisnis Indonesia, p. 6
} 
regarded as uncertain and ambiguous which can jeopardize Indonesia's maritime trading in the long term.

On the other side of the world, UNCITRAL (United Nations Commission on International Trade Law) has adopted four international conventions to standardize the laws governing the carriage of goods by sea. The aspiration of Indonesia to be a developed maritime country would certainly call for a reformation in law governing the carriage of goods by sea. There are multiple choices of international conventions as well as the hybrid versions which are widely applied by Indonesia's major trading partners. It is now the time to decide: which regime is in the best interests of Indonesia?

\section{METHODOLOGY}

This paper employed a two-step comparative analysis method. First step is to compare four UNCITRAL conventions on carriage goods by sea, and second comparison is country-to-country implementation of the international law into their national laws. Ten countries are chosen based on the size of export and import transaction with Indonesia. This paper also applied normative comparison analysis in a purpose to not only explain but also improve the present state of the Indonesia regulations by taking into account the global implementation of UNCITRAL conventions in general and the legal framework in carriage of goods by sea adopted by Indonesia's ten major trading countries. The comparative analysis in this study is also a variation-finding mechanism, which seeks to 'establish a principle of variation in the character or intensity of a phenomenon by examining systematic differences between instances. ${ }^{9}$

\section{Uniformity of Laws}

UNCITRAL, as an institute for the unification of law ${ }^{10}$, thus one of the major global promulgators in the areas of maritime law, defines uniformity as that which removes harriers in international trade. The concept of unification of law rests on the bringing together of legal systems and also finding common ground acceptable to all. ${ }^{11}$ This suggests collaborative compromise, the approach that has long been applied by international and regional organisations in a hope for common adoption of all country members.

Businesses favor uniformity because if the laws are uniform, predictability is higher, thus would lower transaction costs. Predictability is only one advantage of a number of others benefits of uniformity of laws such like the fairness of treating similarly situated

\footnotetext{
9 Tilly, C. (1984). Front Matter. In Big Structures, Large Processes, Huge Comparisons (pp. I-Vi). Russell Sage Foundation. Available from: www.jstor.org/stable/10.7758/9781610447720.1 [Accessed July 9, 2020]

${ }^{10}$ The United Nations Commission on International Trade Law, abbreviated as UNCITRAL, is the core legal body of the United Nations system in the field of international trade law. A legal body with universal membership specializing in commercial law reform worldwide for over 50 years, UNCITRAL's business is the modernization and harmonization of rules on international business

11 UNDROIT. (2020). History and Overview. Available from: https://www.unidroit.org/aboutunidroit/overview [Accessed July 1, 2020]
} 
litigants differently, and the efficiency of making multi-state actors comply with divergent legal standards. ${ }^{12}$

The global nature of international trade has itself entailed the need for uniformity of the laws. Uniform law represents a part of globalization, as it shows interconnectedness among countries around the world and increased communication and awareness of global form of regulatory framework in business transaction. ${ }^{13}$

International trading involves different legal approaches, which have largely been divided into the common law and civil law system. This divergence makes it difficult to find a workable solution in legal conflicts as a result of the substantial discrepancies in the conflict approach of each country with regard to the laws. The transnational character of the maritime industry and its transactions has historically been perceived as separate from domestic law. Therefore the ideal of international uniformity has been always been considered as particularly important to maritime law. ${ }^{14}$

When discussing the need of the uniformity of shipping laws, it has to bring up William Tetley ${ }^{15}$, who first suggested to the maritime community for uniform maritime laws, particularly those relating to carriage of goods by sea. He listed three reasons why it is desirable to have an international convention. It could simplify the international legal system, create legal certainty and attain fairness, equity and just rights and obligations. ${ }^{16}$ Uniformity, from a practical perspective, would also save on costs. Every covered transaction in international trading involves at least two countries so as the parties engaged with the business are numerous; at the very least there are the shippers and the consignees (Sturley, 1995). ${ }^{17}$ Carriers might be from different countries and so may the cargo owners or the underwriters. If a dispute occurs, it could be subject to litigation in any country involved or even in a country where none of the parties are domiciled or have an official presence. Hence, international rules can provide certainty and predictability that are necessary for the parties to make rational and efficient decisions.

Uniformity would be effective and practically useful when it is applied in the national legal system with no reservation. ${ }^{18}$ However, changes are unavoidable when an

\footnotetext{
12 Frost, A. (2008) Overoaluing Uniformity, 94 VA. L. REV. 1567, 1596 Part I

13 Surugiua, M. and Surugiub, C., (2015) International Trade, Globalization and Economic Interdependence between European Countries: Implications for Businesses and Marketing Framework, Procedia Economics and Finance 32 :131 - 138

${ }^{14}$ Myburgh, P., (2000) , Uniformity or Unilateralism in the Law of Carriage of Goods by Sea? 31 Victoria University wellington Law Review 355-381

${ }^{15}$ Professor in maritime law of Mc.Gill University, who has been widely known as the legend in maritime law in recognition of his outstanding contribution to the development of maritime law and maritime law education

${ }^{16}$ Tetley, W., (1987), The lack of Uniformity and the Very Unfortunate State of Maritime Law in Canada, the US, the UK and France, Lloyd's Maritime and Commercial Law Journal 340

17 Sturley, M.F., (1995), Uniformity in the Law Governing the Carriage of Goods by Sea, 26 Journal Maritime Law and Commerce 559

18 Łopuski, J., (2008), Maritime law in the second half of the 20th century. Selected articles, Wydawnictwo Naukowe Uniwersytetu Mikołaja Kopernika, p. 23
} 
international code comes into national enactment. A convention usually contains a provision to only oblige the contracting countries to adopt it but the states would have freedom to enact their own rules.

CMI along with UNCITRAL have tirelessly looked for the greatest acceptance of international conventions on carriage of goods by sea. At present, there are three international conventions on carriage of goods by sea, namely the Hague Rules, the Hague Visby Rules and the Hamburg Rules which have been the major reference for legal disputes on carriage of goods by sea. There will be four sets of rules at play, once the last-signed convention, the Rotterdam Rules, enters into force.

\section{INTERNATIONAL LEGISLATION ON CARRIAGE OF GOODS BY SEA}

\section{The Hague Rules 1924}

\section{Historic Background}

The first related international convention established was the 'Brussels Convention for the Unification of Certain Rules of Law Relating to Bills of Lading' or popularly known as 'the Hague Rules' in 1924, which were later adopted by 26 participating parties including the major maritime nations. ${ }^{19}$

The Hague Rules were mainly based on the Harter Act of 1893 since many provisions in the convention are reproduced provisions found in the Harter Act. The Harter act was US congress-enacted rules, which constituted the world's first legislative attempts to allocate the risk of loss in ocean transportation between carrier and cargo interest (Sturley, 1983) 20

The Hague Rules were seen as a 'compromise' between carriers and shippers from developed countries and were not intended to be a comprehensive regulation of carriage of goods by sea, but rather affirmed certain basic responsibilities of the carrier and shippers by setting forth exemption from carrier liability, and providing for limitation of carrier liability. ${ }^{21}$ Thus, the carrier would be able to opt out of certain defined responsibilities and the parties were free to negotiate the remaining terms. This is the most important effect of the Hague Rules existence (Wilson, 2008). ${ }^{22}$

However, the Hague Rules only lasted for the first half of this century when the trading was still carried out in the traditional fashion. Technology and communication had developed in the shipping industry by increasing use of containerization and navigational technology that forced the $\mathrm{CMI}$ to seek better legislation.

\section{The Defects of the Hague Rules}

\footnotetext{
${ }^{19}$ Astle , W.E, (1981), The Hamburg Rules The Hamburg Rules: An appreciation of the cause and effect of the amendments to the Hague Rules and the Hague-Visby Rules, Fairplay

${ }^{20}$ Sturley, M.F., (1983), Changing Liability Rules and Marine Insurance:Conflicting Empirical Arguments about Hague,Visby, and Hamburg in a Vacuum of Empirical Evidence, 24 Journal Maritime Law and Commerce 119

${ }^{21}$ Force, R., (1996), A Comparison of the Hague, Hague-Visby, and Hamburg Rules: Much Ado About (?), 70 Tulane Law Review 2052

${ }^{22}$ Wilson, J.F., (2008), Carriage of Goods by Sea, Longman
} 


\section{Scope of Application}

The scope of application only applies to the outbound shipment which is shipment from a port of contracting party to a port of a non-contracting state. Thus, the rules are not applicable for outbound shipment from any port of a non-contracting state to a port of a contracting state. This defect was raised by a well-known case on conflict of law namely Vita Food Case (Vita Food Product v Unus Shipping Co [1939] AC 277) which enabled the Hague Rules to be exempted by a choice of law clause for a jurisdiction in a non-contracting state (Reynolds, 1990). ${ }^{23}$

\section{A Short Period of Responsibility}

The rules only cover the liability of carriers from "the period from the time when goods are loaded on to the time they are discharged from the ship", a period which is referred to as 'tackle to tackle' (Article I (e)). Therefore, the carrier would not be liable for damage of a cargo while it sat on the dock or was stored in the warehouse prior to or after shipping.

\section{Low Limitation of Financial Liability}

The Hague Rules have been widely criticized for setting the amount of carrier's liability limitation too low, for only 100 pounds per package or unit (Article IV (5)). It has no method of unit limitation for bulk cargoes and difficulty in determining the liability limitation for a container whether in package or unit. ${ }^{24}$ This technique of expressing the limitation amount became unpractical for current means of compensation and liability.

\section{Inadaptability to Technology and Communications Development}

The widely used electronic communications robustly influence the increasing use of electronic $B / L$ (Bills of Lading) in shipping transactions by the introduction of Electronic Data Interchange (Article $\mathrm{X}(12)$ ) which has been developed to replace the paperless $\mathrm{B} / \mathrm{L}$. ${ }^{25} \mathrm{Hence}$, the Hague Rules were irrelevant and incompatible to the new system of seaborne trading.

\section{The Hague Visby Rules 1968}

\section{Historic Background}

$\mathrm{CMI}$ adopted a protocol of the Hague Rules amendments signed at the city of Visby on the island of Gotland in Baltic. These amendments to the Hague Rules are officially titled as 'Protocol to Amend the International Convention for the Unification of Certain Rules of Law Relating to Bills of Lading" which entered into force on February 23, 1968.

\footnotetext{
${ }^{23}$ Reynolds, F., (1990), The Hague Rules, the Hague-Visby Rules and the Hamburg Rules, 7 MLAANZ Journal 19

24 Reynolds, F., (1990), The Hague Rules, the Hague-Visby Rules and the Hamburg Rules, 7 MLAANZ Journal 19

${ }^{25}$ Hasan, Z., and Ismail, N., (2007), The Weaknesses of the Hague Rules and the Extent of Reforms made by the Hague-Visby Rules, Malayan Law Journal 7
} 
The next amendment, namely the 'SDR Protocol' was further made to account for currency imbalances in December 21, 1979. ${ }^{26}$

The Hague Rules were widely regarded as adverse to carriers, hence the Visby amendments (hereinafter HVR) which were to some extent put forward by carrying interests. The amendments contain provisions which are intended to remedy defects noted in the Hague Rules to which carriers had drawn attention. ${ }^{27}$ The HVR have now either been ratified or adopted as domestic legislation by almost one third of the parties to the Hague Rules including some leading maritime nations such as Belgium, France, the Scandinavian countries, South Africa and the United Kingdom (Lourens, 1999). The remaining two third of the Hague Rules contracting states, accordingly have both Hague Rules and HVR standing side by side (Carr, 2010). The amendments modified the Hague Rules in several respects, most notably, the limitation of the carrier's duties and the laundry lists of immunities to the carrier, including nautical fault defense (Article IV.2).

\section{The Shortcomings of HVR}

One major concern was the exception of a ship's negligent management which was categorized by different aspects of negligence, thus the categorization would apply different approaches. Further, the rules are difficult to interpret and have also created uncertainty. There is no proper provision to identify the Hague Rules' carrier. Accordingly this has led to immeasurable problems relating to demise clauses and succeeding carriers. ${ }^{28}$ The period of the carrier's liability is found still too limited and deck cargo is still excluded from the subject matters.

\section{The Hamburg Rules 1978}

\section{Historic Background}

The Hamburg Rules were adopted by UNCITRAL in March 1978 and after waiting for more than a decade, it came into effect on November 1, 1992. The countries which have ratified the convention are mostly developing countries. The Hamburg Rules was said to have better rules than HVR, as they were the first truly comprehensive attempt to codify the allocation of risks between vessel interest and cargo interests. ${ }^{29}$

\section{Salient Features of the Hamburg Rules}

The first and greatest change was the elimination of the defense of the nautical and managerial fault, unless the carrier can prove that it/its servants/agents "took all measures that could be reasonably required to avoid" (Article 5 (1)). The Hamburg rules were made applicable to the delay in delivery of the goods, which was uncertain

26 CMI $\quad$ Year 2009 (2009) available from:

\section{http://www.comitemaritime.org/year/2009/pdffiles/YBK_2009.pdf [accessed 2020, 1 July]}

27 Reynolds, F., (1990), The Hague Rules, the Hague-Visby Rules and the Hamburg Rules, 7 MLAANZ Journal 19

28 Diamond, A. (1978), The Hague-Visby Rules, Lloyd's Maritime and Commercial Law Journal

29 Bauer, R.G., (1993), Conflicting Liability Regimes: Hague-Visby v Hamburg Rules-A Case by Case Analysis, 24 Journal Maritime Law and Commerce 53 
under the HVR, with up to $2 / 1 / 2$ times the amount of freight cost. For the first time deck cargo was included under liable goods as well as cargo moving without a B/L (Article 9 (1)).

The other major point was the maximum limit of carrier's liability which was increased from 665 SDR under the HVR to 835 SDR per package. Shippers could claim damages based on the weight of the cargo instead of the value of the package with a maximum recovery of 2.5 SDRs per kilo, approximately \$1.59 per Ib. or \$1169 per package, whichever is higher (Article 6 (1)).

Arbitration and jurisdiction, for the first time, were included by the new rules (Article 21 and 22); hence it provides a wider choice of courts to the parties of carriage. The application scope was extended from tackle- to-tackle to port-to-port movement which was defined as 'any contract whereby the carrier undertakes against payment of freight to carry goods by sea from one port to another" (Article 1(6)).

However, there have been global developments, which have rendered the HVR and/or the Hamburg Rules obsolete. The massive increase in container traffic demands better legislation than the simple package under the 1968 HVR while the mass use of electronic communication in the issue and transfer of $\mathrm{B} / \mathrm{L}$ required an accommodating legislation. ${ }^{30}$ Lastly, new legislation is required to respond to increased market globalization, even within the liner markets as they become more concerned about the carriage of goods since the liner term is not only about exports matter, but also an integral part of serial supply chains, for which new legislation provides flexibility in freedom of contracts. A new law becomes urgently and necessarily required.

\section{The Rotterdam Rules}

\section{Historic Background}

On 11 December 2008, the UNCITRAL adopted the Rotterdam Rules as an attempt to bring back the uniformity of law in the field of maritime carriage by replacing the multiplicity of liability regimes currently in existence as well as other regional hybrids. Many of its provisions are expected to represent significant breakthroughs in an area previously defined by a certain divergence between the HVR and Hague Rules. ${ }^{31}$

The Rotterdam Rules run to 96 articles under 18 chapters, more complex and much numerous compare to their predecessors, the Hague Rules that run to 16 articles with amendments by Visby Rules, while the Hamburg Rules consist of 34 articles and two annexes. What are the features of the Rotterdam Rules, which make them significantly distinguishable from its predecessors?

The rules are bold and ambitious, in terms of the extensive number and detail of provisions in the new convention, and accordingly the law has become flooded with

\footnotetext{
30 Staniland, H., (2009), Preface, in Y. Baatz and others (eds) The Rotterdam Rules: A Practical Annotation pp.v-vi

${ }^{31}$ Alba, M., (2008), Electronic Commerce Provisions in the UNCITRAL convention on contract for the International Carriage of Goods Wholly or Partly by Sea', Texas International Law Journal 388
} 
words and missions which arguably would be unsuccessful to cover all in accurate detail. ${ }^{32}$

\section{Key Provisions}

a. Scope and Period of Application

It requires for the convention to apply that the place of the receipt or loading or discharge or delivery of goods has to be in the contracting country. The period of application is 'door-to-door'; from the time when the goods are received to the time the goods are delivered. It is not restricted to tackle-to-tackle (Hague Rules) or port-toport (Hamburg Rules). This eliminates the carrier's liability to take benefit of a system of network liability which imposes different liability based on what stage the loss or damage arises (SITPRO's guide to the Rotterdam Rules, 2010).

b. Maritime Performing Parties Recognition, Himalaya Clause and Electronic Commerce

The Rotterdam Rules introduced a new term of "maritime performing party" to which the obligations, liabilities and limitation of carriers are extended (Article 19). It is a party other than the contracting carrier who performs any part of the sea leg or provides additional services to the sea leg such like stevedores and terminal operators who possess liability as the same as the carrier when they are in charge of the cargo.

\section{c. Volume Contracts}

Volume contracts are defined as "a series of shipments of specified quantities of goods during an agreed period of time" (Article 80). There is freedom to derogate from the Rotterdam Rules in respect of volume contracts as long as it prominently states the derogation from the rules. ${ }^{33}$ Nevertheless, the provisions of seaworthiness and crewing and equipping, the obligation of information, dangerous goods, the limits of liability and the loss of right to limit liability are unable to be omitted.

The introduction of the maritime performing parties has clearly shown the anticipation made by the Rotterdam Rules in respect of Himalaya clause, a clause in a bill of lading or transportation contract purporting to extend liability limitations which benefit the carrier, to others who act as agents for the carrier such as stevedores or longshoremen

Thus, the convention authorizes the automatic Himalaya clause protection to every maritime performing party regardless of whether the relevant contract incorporates a Himalaya clause. ${ }^{34}$ Related to electronic commerce, the convention ensures that the eligibility of any electronic transport records, whether negotiable or not, or other information in electronic forms are similar to their paper documents (Article 8-10).

\footnotetext{
32 Thomas, D.R., (2008), And Then There Were the Rotterdam Rules, 14 Journal of International Maritime Law 189-190

33 Mukherjee, P.K., and Bal, A.B., (2009), A legal and Economic Analysis of the Volume Contract Concept Under the Rotterdam Rules:Selected Issues in Perspective, 40 Journal of Maritime Law and Commerce, 579-608

${ }^{34}$ Sturley, M.F., (2008), Modernizing and Reforming U.S. Maritime Law: The impact of the Rotterdam Rules in the United States' 44 Texas International Law Journal 449
} 


\section{d. Provisions on Liabilities of Carriage for Loss Damage or Delay}

The monetary maximum limit of a carrier's liability is extended to 875 SDR (Special Drawing Rights) per package and 3 SDR units per kilogram of gross weight whichever is higher (Article 17). The period limit for any claim is extended from one year under its predecessor to two years (Article 62 (1)). For the delay in delivery, which causes loss, the damages are limited to a multiple 2.5 times the freight payable on the goods delayed. Notice of delays must be given within 21 days from the date of agreed delivery.

e. Jurisdiction and Arbitration

Jurisdiction and arbitration were firstly included in the Hamburg Rules, but the new convention provides more detailed provisions (Chapter 14 and 15). In both jurisdiction and arbitration provisions, a claimant has broader options of courts namely "domicile of the carrier", "place of receipt", "delivery of the goods", or "load/discharge port" in which to bring claims. Nonetheless, a state shall express the 'opt-in' jurisdiction clause in their enactment to have a legal effect (Article 66).

\section{GLOBAL PRACTICE}

\section{Current Global Position}

The UK, France and Canada had adopted the HVR by virtue of its own legislation. The UK adopted the HVR by the COGSA in 1971. France enacted the Hague Rules for international shipment in 1936 and then amended them with the Visby Rules in 1977 and 1987. France is not an enactor of the Hamburg Rules, yet certain provisions of the rules were incorporated in their domestic legislation. ${ }^{35}$ Canada adopted the Hague Rules with "Carriage of Goods by Water Act" 1936, which was revoked in the act in 1993 adopting HVR. Canada takes a somewhat parallel approach as Australia by providing provision for future adoption of the Hamburg Rules at five-year intervals. Yet, after two reviews in 1999 and 2001, it continues the enforcement of the Hague Rules. Canada naturally would like to follow the US because the US is Canada's second largest trading partner in terms of sea trade.

Scandinavian Countries, i.e. Finland, Norway, Sweden and Denmark have exclusively enacted the Hamburg Rules in their HVR version legislation of 1994The HVR have also been adopted by Belgium, Hong Kong, Italy, Netherlands, Spain and New Zealand, each country taking some liberties in adoption of the rules into its own legislation. ${ }^{36}$

In the CMI yearbook 2009, the Hague Rules had been adopted by 85 countries and 14 have later amended their laws with the Visby Rules (CMI Yearbook, 2009). Thirty-three states adopted the Visby Rules 1968 while only 25 states incorporated the SDR Protocol 1979 in their legislation. The number is certainly much higher when countries applying the hybrid of the HVR and the Hamburg Rules are included. The Hamburg

\footnotetext{
35 Sturley, M.F., (1995), Uniformity in the Law Governing the Carriage of Goods by Sea, 26 Journal Maritime Law and Commerce 559

${ }^{36}$ Mandelbaum,S.L., (1996), Creating Uniform Worldwide Liability Standards for Sea Carriage of Goods Under the Hague, COGSA, Visby and Hamburg Conventions, 23 Transport Law Journal 477
} 
Rules 1978, which came into force in 1992, attracted only 33 states, most of which are developing countries.

\section{Indonesia's Principal Trading Partner Countries}

Tetley (1987) argued that the international uniformity could not be achieved unless one's major trading partners do the same. It was proven when the US adopted the Hague Rules with the COGSA 1936. A flurry of ratifications followed in due course. A country may 'wait-and-see' to what the response of their major trading country partners and the international practices, before deciding its position whether to follow the trend or to sustain the exiting one. From the 2018 Indonesian export and import data, the top-ten major trading partners with Indonesia in terms of trade value, are: Japan, Singapore, China, US, Malaysia, South Korea, India, Thailand, Australia and Germany. ${ }^{37}$

\section{Japan}

Japan has become a member of the HVR with the full support of both Japanese shipowners and shippers. It has ratified the Hague Rules along with the modifications from the HVR in 1992. During the Rotterdam Rules making process, Japan played an important role during the drafting and negotiation; surprisingly they are yet to sign the convention.

\section{Singapore}

Singapore has been Indonesia's second biggest trading partner for the last seven years. They have enacted the HVR with COGSA 1972 which was later modified in 1995 in order to accommodate the technology development in sea trading. Meetings and discussions with concerned parties are still underway to examine the benefit of the Rotterdam Rules to Singapore's shipping industry. ${ }^{38}$

\section{China}

The Chinese Maritime Code 1993 leaned profoundly toward the Hague Rules while also including the Visby amendments and combining the characteristics of the Hamburg Rules. ${ }^{39}$ China, as with Japan, took a leading role in the Rotterdam Rules drafting process but they are yet to sign the convention.

\section{The United States (U.S.)}

The U.S. is the world's largest trading nation, with international trading approaching over \$1 trillion annually (Mandelbaum, 1996). They are actually the first country to

\footnotetext{
37 Department of Commerce of Republic of Indonesia (2019) available from: <http://www.depdag.go.id/content/statistic/18/> [accessed 2010, May 2020]

38 Hamid, A.G., (2004) , Whiter Malaysia: The Hague-Visby or Hamburg Rules?, 4 INSAF (Journal of Malaysian Bar) 86

${ }^{39}$ Tetley, W., (1987), The lack of Uniformity and the Very Unfortunate State of Maritime Law in Canada, the US, the UK and France, Lloyd's Maritime and Commercial Law Journal 340
} 
adopt an international approach to legislation on maritime trading with the adoption of the Harter Act 1893. This act was then provisionally adopted by the Hague Rules in 1924 which were later ratified by the U.S. with the COGSA 1936 with some minor amendments in order to suit the shipping practices during the time.$^{40}$

The U.S. adopted neither the Visby amendments nor the Hamburg Rules. In the draft of the U.S. COGSA 1998, the U.S. adopted a hybrid between HVR and HAR, and once it is approved by the senate and comes into force, it will add to the existing hybrid regimes. ${ }^{41}$ The COGSA 1998 would be further postponed since the Rotterdam Rules were adopted by UNCITRAL. During the Rotterdam Rules' drafting, the U.S. played the most significant role and signed the rules at the signing ceremony. This implicitly means that U.S. deleted the agenda to forgo COGSA 1998 (the hybrid of HVR and Hamburg Rules) but adopt the Rotterdam Rules instead.

At the global level, the ratification of the convention maintains the trust of other countries in the U.S. leadership of the international maritime community. The rest of the world is now paying attention to what China decides with respect to the Rotterdam Rules.

Malaysia

Malaysia shares the same legislative history with Singapore, yet they were less responsive to adopt an international legislation in their legislation. Malaysia ratified the Hague Rules with COGSA 1950 and with some minor modifications in 1995 . There were discussions at the ministry level to revoke the act and replace it with a new regime incorporating the HVR and other maritime conventions. In 2003, the Carriage of Goods by Sea Bill 1970 was submitted to Parliament to incorporate some provisions of the HVR, but the bill was never passed ${ }^{42}$

\section{South Korea}

Korea was not a contracting state to any of the international carriage of goods by sea acts. Nevertheless, Korea takes an approach by using the uniform law as a model when enacting its domestic law on the subject. Korean Commercial Codes, amended in 1993, contain certain provisions of the HVR. ${ }^{43}$ The major amendments inspired by the Hamburg Rules are the ship-owners liability limitation to the value of the vessel or to the amount of "15,000 won per ton of tonnage," whichever was the lower. Korea also for the first time introduced the package limitation although the amount has been slightly different which is 500 SDR per package rather than 666.67 SDRs per HVR, and there is no weight-based restriction amount provided.

\footnotetext{
${ }^{40}$ Sturley, M.F., (2008), Modernizing and Reforming U.S. Maritime Law: The impact of the Rotterdam Rules in the United States' 44 Texas International Law Journal 449

${ }^{41}$ Lourens, M., (1999) , An Overview of the Regimes Governing of Goods by Sea, 10 Stellenbosch Law Review 246

${ }^{42}$ Joseph, J.M., (1998), Carriage Goods by Sea: Hague-Visby for Malaysia?, 1 Malayan Law Journal, 2

${ }^{43}$ Kozuka, S., (2003), Carriage of Goods and legal uniformity in the Asia-Pacific Region, 8 Uniform Law Review 255-264
} 
India

India has adopted the Hague Rules 1924 with COGSA 1925. The COGSA 1925 is applicable in respect of the carriage of goods by sea in ships carrying goods inward from outside India and outward from India. ${ }^{44}$ India is not a party of the Hamburg Rules, but they apply the maximum liability provision 666.67 SDR per package or 2 SDR per kilogram as per the Hamburg Rules.

\section{Thailand}

Thailand has passed COGSA 1992 which is majorly based on the HVR with several additions from the Hague Rules. The Hamburg Rules provisions of 'port-to-port period of responsibility and liability for delay which is limited to 2.5 times the freight payable were also enacted in their COGSA.

\section{Australia}

Australia incorporated the Hague Rules and two Visby amendments in their COGSA 1991 which contained an 'automatic trigger' mechanism to automatically replace the HVR by the Hamburg Rules after three years, unless otherwise specified by the government. ${ }^{45}$ Nevertheless, the automatic scheme remained unused due to the strong opposition to the Hamburg Rules. COGSA 1997 was then passed to replace the provision of the three year automatic replacement with a five-year interval review.

\section{Germany}

Germany incorporated the Hague Rules 1924 into the German Commercial Code (The Handelsgesetzbuch/HGB) in 1937 and incorporated the two Visby amendments into the HGB after taking time for a while in considering whether to ratify the Hamburg Rules or follow the crowd to adopt the HVR (Tetley, 1999). With respect to the Rotterdam Rules, like other European states, Germany is sitting in a neutral position and waiting until the US, China and Japan make their moves.

\section{INDONESIA'S POSITION}

\section{An Overview of the Indonesian Legal System}

Indonesia is a civil-law country in South East Asia directly surrounded by common law countries, like Australia, Malaysia, Singapore, Brunei and the Philippines. Indonesian legal philosophy has been considerably influenced by Dutch legal system, which is classified as civil law.

In the Indonesian civil law system, prominence is placed on codified law passed by parliament, supplemented by regulations, decrees and orders issued by the president,

\footnotetext{
${ }^{44}$ Kiran, R.B.K., (2007), The law of Liability for Maritime Accidents in India, 38 Journal of Maritime Law and Commerce 43

${ }^{45}$ Tetley, W., (2009), A Critique and the Canadian Response to the Rotterdam Rules', in D.R.Thomas (ed) A new convention for the carriage of goods by sea : the Rotterdam Rules; an analysis of the UN Convention on Contracts for the International Carriage of Goods Wholly or Partly by Sea, Lawtext Publishing Ltd
} 
ministers and other executive bodies. The doctrine of binding precedent is not applicable under the Indonesia legal system, like other countries with a civil law tradition. Thus case law, which serves as a substantial source of law in common law jurisdiction, has little or no role in Indonesian law.$^{46}$

Single decisions of the courts are recognized and enforced only upon the parties and not upon others in future cases. Nevertheless, when courts have repeated preceding decisions more than once, they would have persuasive authority. In few cases, a court will decide owing to such established decisions, only those established decisions may be cited as "case law". ${ }^{47}$

The Indonesian laws of contract are still governed by Dutch colonial codes, civil codes (Burgerlijk Wetboek voor Indonesie) and commercial codes (Wetboek van Koophandel voor Indonesie), both came into force in 1848. After Indonesia officially welcomed foreign investment in 1967 and in the subsequent global economy, Indonesia laws that particularly deal with commercial law have been largely influenced by the U.S. contract formats. ${ }^{48}$ This is enough to explain that Indonesia civil law is undergoing a silent conversion in the direction of U.S. law.

\section{Indonesian Commercial Code}

Indonesian laws with respect to carriage of goods by sea are codified under the commercial code of 1848. The codes are divided into three books -the law merchant in general, rights and obligation arising from shipping and insolvency of merchant (Book I). The rules on carriage of goods by sea are incorporated in Book II under chapter V about Ship Charters from articles 309 to 747. Carriage of goods by sea is governed under a specific sub chapter VA from article 466 to $517 \mathrm{~d}$. The rest of the articles within Chapter $\mathrm{V}$ provide general matters related to the carrier, shipper, the employment agreement between the carrier and its servants and the provision on voyage and time charter. The provisions on carriage of goods by sea actually took some inspiration from the Hague Rules.

The Netherlands ratified the Hague Rules which were revoked by the ratification of the Visby and SDR Protocol, while Indonesia 2qw still stuck with its largely obsolete 1848 version. A new draft maritime law was actually prepared by a team of experts 20 years ago but no consensus was made on enactment of international conventions. In practice, parties in carriage of goods contract take proactive initiative if they prefer the international conventions to be included in their contract, through including their interest by references incorporated into a $\mathrm{B} / \mathrm{L}$ or other contract of carriage, which becomes binding upon the parties as a contractual obligation. ${ }^{49}$

\footnotetext{
46 Tabalujan, B.S., (2010), An Indonesian Legal System-An Overview. Available from: http://alterisk.ru/lj/IndonesiaLegalOverview.pdf [accessed 2020, June 23]

47 Gunanto, H., (1995), The Impact of U.S. Law Propositions on Indonesian Commercial Law, Loyola Law Review 1051

48 Gunanto, H., (1995), The Impact of U.S. Law Propositions on Indonesian Commercial Law, Loyola Law Review 1051

${ }^{49}$ Ganie, M.I., and Mills, K., (2007), Indonesia, in W. Tetley, Marine Cargo Claims, Carswell Company
} 
The carrier's limitation liability determined by the code was too low compared to current trading currency and had no package limitation provided therein. The provision on period responsibility was also absent to define either at the time the goods are loaded onto the ship to the time they are unloaded from it as per Hague Rules, or during the entire period of the goods at the port of loading until they are discharged as the Hamburg Rules applies. Indonesian commercial codes also remain silent on jurisdiction and arbitration.

One other characteristic apart from features provided by the international conventions, which were "demise" or an "identity of carrier" clause, a common clause in carriage goods by sea under common law, is not governed under Indonesian law. The use of a demise clause has in practice led to situations in which the plaintiff sued the "wrong" carrier and by the time the plaintiff sued the actual carrier, the one year period of bar order under Indonesian law had expired and as a result the plaintiff was abandoned without any remedy. In short, there appears in essence that no advantage arising from the use of demise clause under Indonesia law.

Matters on containerization and electronic $B / L$ are far beyond the remit of the Indonesian Commercial Codes 1898. Therefore, any matter outside the application scope of the codes would rely on the interpretation of the clause incorporated in the B/L.

\section{RECOMMENDATIONS AND CONCLUSION}

Practices applied by the ten countries, which were trading partners to Indonesia clearly indicates that a large proportion, except the US, India and Malaysia, have adopted either the HVR or a hybrid regime of HVR and Hamburg Rules like China and Thailand. While the U.S., India and Malaysia are still in the shadow of the Hague Rules, there had been movements underway in these countries to the prospect of ratifying the HVR before the Rotterdam Rules are adopted.

The current global practice discloses that the majority of countries, including large shipping states where carrier's interests are overriding, enact the HVR. The HAR attracted an insignificant number of countries, most of which were developing countries where cargo-owner's interests are dominant. Other major maritime states i.e. the United Kingdom, Canada, France and Italy have also adopted the HVR into their own legislation, whereas Scandinavian countries preferred to ratify the Hamburg Rules.

The Rotterdam Rules have recently listed on the option cluster and become a reliable choice for countries seeking the most sophisticated legal approach to shipping developments. Although to date no country has yet adopted the convention, Indonesia shall not lose sight of the prospect of its adoption and enforcement in the near future.

Indonesia is undoubtedly in need of a new regime on the carriage of goods by sea. Among a range of options from their trading partners and the global practice, which regime is in the best interest of Indonesia? The widespread use of EDI and intermodal transport in Indonesia automatically excludes the Hague Rules as an option. The HVR is a favorable regime in global practice including Indonesia's trading partners, but as 
Indonesia is a country of shippers rather than carriers, the Hamburg Rules would be a preference with respect to the liability limitation leaning to the shippers.

Against this background, it would be in the best interest of Indonesia to entirely replace the provisions on carriage of goods by sea in its 1898 Commercial Code with a new regime incorporating a hybrid regime of the HVR and Hamburg Rules. Indonesia should adopt the HVR's provisions on 'tackle-to-tackle' period of responsibility for noncontainerized goods, due diligence obligation of the carrier, carriers' duty of care for cargo, financial limitation of 666.67 SDRs per package-2 SDRs per kg for loss and damage. The liability limitation under HVR is actually lower than Hamburg Rules, thus it contributes less benefit to the cargo-owner. However, Indonesia should act in concert with international practice which mostly adopts the HVR version.

The new Indonesian regime should not been put on hold until the Rotterdam Rules enter into force, whether next year or a decade later. It would be impressive if the new legislation provides a provision for automatic replacement, such as the Australian and Canadian COGSA by the Rotterdam Rules, at a five-year interval as a sign to the world about the Indonesian commitment to be a maritime nation with strong support of upto-date regulations. Alternatively, a signature on the Rotterdam Rules would also demonstrate the same intention.

\section{BIBLIOGRAPHY}

Alba, M., (2008), Electronic Commerce Provisions in the UNCITRAL convention on contract for the International Carriage of Goods Wholly or Partly by Sea', Texas International Law Journal 388

Astle, W.E, (1981), The Hamburg Rules The Hamburg Rules: An appreciation of the cause and effect of the amendments to the Hague Rules and the Hague-Visby Rules, Fairplay

ASEAN (n.d.). ASEAN Member States. Available from: https://asean.org/asean/aseanmember-states/ [Accessed May 20, 2020]

ASEAN (n.d.). ASEAN Economic Community. Available from: https://asean.org/aseaneconomic-community/ [Accessed June 21, 2020 https://asean.org/aseaneconomic-community/

Azka R. (2019, August 14) Revisi UU Pelayaran: INSA: Waspadai Intervensi Asing, Bisnis Indonesia

Baatz, Y., and others (eds), (2009), The Rotterdam Rules: A Practical Annotation, Informa Law from Routledge

Bauer, R.G., (1993), Conflicting Liability Regimes: Hague-Visby v Hamburg Rules-A Case by Case Analysis, 24 Journal Maritime Law and Commerce 53

Berlingieri, F., (1987), Uniformity in Maritime Law \& Implementation of International Convention, 18 Journal Maritime Law and Commerce 321

Carr, I., (2010), International trade law: with contributions on private international law, Peter Stone 
CMI Year Book 2009 (2009) available from:

http://www.comitemaritime.org/year/2009/pdffiles/YBK_2009.pdf [accessed 2020, 1 July]

Cribb, R., \& Ford, M. (2009). Indonesia as an Archipelago: Managing Islands, Managing the Seas. In R. Cribb \& M. Ford (Eds.), Indonesia beyond the Water's Edge: Managing an Archipelagic State (pp. 1-27). ISEAS-Yusof Ishak Institute.

Department of Commerce of Republic of Indonesia (2019) available from: <http://www.depdag.go.id/content/statistic/18/> [accessed 2010, May 2020]

Diamond, A. (1978), The Hague-Visby Rules, Lloyd's Maritime and Commercial Law Journal

Force, R., (1996), A Comparison of the Hague, Hague-Visby, and Hamburg Rules: Much Ado About (?), 70 Tulane Law Review 2052

Ganie, M.I., and Mills, K., (2007), Indonesia, in W. Tetley, Marine Cargo Claims, Carswell Company

Green, D.J., (2007), Bridging the ASEAN Development Divide: A Regional Overview, 24 ASEAN Economic Bulletin 30

Gunanto, H., (1995), The Impact of U.S. Law Propositions on Indonesian Commercial Law, Loyola Law Review 1051

Hamid, A.G., (2004) , Whiter Malaysia: The Hague-Visby or Hamburg Rules?, 4 INSAF (Journal of Malaysian Bar) 86

Hasan, Z., and Ismail, N., (2007), The Weaknesses of the Hague Rules and the Extent of Reforms made by the Hague-Visby Rules, Malayan Law Journal 7

Joseph, J.M., (1998), Carriage Goods by Sea: Hague-Visby for Malaysia?, 1 Malayan Law Journal, 2

Kiran, R.B.K., (2007), The law of Liability for Maritime Accidents in India, 38 Journal of Maritime Law and Commerce 43

Kozuka, S., (2003), Carriage of Goods and legal uniformity in the Asia-Pacific Region, 8 Uniform Law Review 255-264

Lopuski, J., (2008), Maritime law in the second half of the 20th century. Selected articles, Wydawnictwo Naukowe Uniwersytetu Mikołaja Kopernika, p. 23

Lourens, M., (1999), An Overview of the Regimes Governing of Goods by Sea, 10 Stellenbosch Law Review 246

Mandelbaum,S.L., (1996), Creating Uniform Worldwide Liability Standards for Sea Carriage of Goods Under the Hague, COGSA, Visby and Hamburg Conventions, 23 Transport Law Journal 477

Moore, J.C., (1979), The Hamburg Rules, 10 Journal Maritime Law and Commerce 2 
Mukherjee, P.K., and Bal, A.B., (2009), A legal and Economic Analysis of the Volume Contract Concept Under the Rotterdam Rules:Selected Issues in Perspective, 40 Journal of Maritime Law and Commerce, 579-608

Myburgh, P., (2003), Uniformity or Unilateralism in the Law of Carriage of Goods by Sea? 31 Victoria University wellington Law Review 355-381

Parameswaran, P. (2015). Indonesia's Maritime Ambition: Can Jokowi Realise It? RSIS Commentary

Reynolds, F., (1990), The Hague Rules, the Hague-Visby Rules and the Hamburg Rules, 7 MLAANZ Journal 19

Sirait, Y. H., \& Ai Permanasari. (2020). Marine Litter Management Policy: State Responsibilities And The Role Of Local Wisdom. Mulawarman Law Review, 5(1), 18-28. https://doi.org/10.30872/mulrev.v5i1.307

SITPRO's Guide to the Rotterdam Rules <http://www.sitpro.org.uk/reports/rotterdamrulesguide.pdf> [accessed 2020, 15 June]

Staniland, H., (2009), Preface, in Y. Baatz and others (eds) The Rotterdam Rules: A Practical Annotation pp.v-vi

Sturley, M.F., (1983), Changing Liability Rules and Marine Insurance:Conflicting Empirical Arguments about Hague,Visby, and Hamburg in a Vacuum of Empirical Evidence, 24 Journal Maritime Law and Commerce 119

Sturley, M.F., (1995), Uniformity in the Law Governing the Carriage of Goods by Sea, 26 Journal Maritime Law and Commerce 559

Sturley, M.F., (2008), Modernizing and Reforming U.S. Maritime Law: The impact of the Rotterdam Rules in the United States' 44 Texas International Law Journal 449

1 Surugiua, M. and Surugiub, C., (2015) International Trade, Globalization and Economic Interdependence between European Countries: Implications for Businesses and Marketing Framework, Procedia Economics and Finance 32

Tabalujan, B.S., (2010), An Indonesian Legal System-An Overview. Available from: http://alterisk.ru/lj/IndonesiaLegalOverview.pdf [accessed 2020, June 23]

Tetley, W., (1987), The lack of Uniformity and the Very Unfortunate State of Maritime Law in Canada, the US, the UK and France, Lloyd's Maritime and Commercial Law Journal 340

Tetley, W., (1999), The proposed New United States Senate COGSA: The Disintegration of Uniform International Carriage of Goods by Sea Law, 30 Journal Maritime Law and Commerce 610

Tetley, W., (2009), A Critique and the Canadian Response to the Rotterdam Rules', in D.R.Thomas (ed) A new convention for the carriage of goods by sea : the Rotterdam Rules; an analysis of the UN Convention on Contracts for the International Carriage of Goods Wholly or Partly by Sea, Lawtext Publishing Ltd 
Thomas, D.R., (2008), And Then There Were the Rotterdam Rules, 14 Journal of International Maritime Law 189-190

Tilleke \& Gibbins, (2003), Maritime Claims, Thailand Legal Basics 151

Tilly, C. (1984). Front Matter. In Big Structures, Large Processes, Huge Comparisons (pp. I-Vi). Russell Sage Foundation. Available from: www.jstor.org/stable/10.7758/9781610447720.1 [Accessed July 9, 2020]

Vita Food Product v Unus Shipping Co [1939] AC 277

Wilson, J.F., (2008), Carriage of Goods by Sea, Longman

World Bank (n.d.) The World Bank in Indonesia. Available from: https://www.worldbank.org/en/country/indonesia/overview [Accessed May 20, 2020]

Yu, R.S., and Peck, J., (1993), The Revisited Maritime Section of the Korean Commercial Code, 403 Lloyd's Maritime and Commercial Law Journal 408 